\title{
Will the skill-premium in the Netherlands rise in the next decades?
}

Citation for published version (APA):

Dupuy, A. (2007). Will the skill-premium in the Netherlands rise in the next decades? Applied Economics, 39(21), 2723-2731. https://doi.org/10.1080/00036840600749441

Document status and date:

Published: 01/01/2007

DOI:

10.1080/00036840600749441

Document Version:

Publisher's PDF, also known as Version of record

\section{Please check the document version of this publication:}

- A submitted manuscript is the version of the article upon submission and before peer-review. There can be important differences between the submitted version and the official published version of record.

People interested in the research are advised to contact the author for the final version of the publication, or visit the DOI to the publisher's website.

- The final author version and the galley proof are versions of the publication after peer review.

- The final published version features the final layout of the paper including the volume, issue and page numbers.

Link to publication

\footnotetext{
General rights rights.

- You may freely distribute the URL identifying the publication in the public portal. please follow below link for the End User Agreement:

www.umlib.nl/taverne-license

Take down policy

If you believe that this document breaches copyright please contact us at:

repository@maastrichtuniversity.nl

providing details and we will investigate your claim.
}

Copyright and moral rights for the publications made accessible in the public portal are retained by the authors and/or other copyright owners and it is a condition of accessing publications that users recognise and abide by the legal requirements associated with these

- Users may download and print one copy of any publication from the public portal for the purpose of private study or research.

- You may not further distribute the material or use it for any profit-making activity or commercial gain

If the publication is distributed under the terms of Article $25 \mathrm{fa}$ of the Dutch Copyright Act, indicated by the "Taverne" license above, 


\title{
Will the skill-premium in the Netherlands rise in the next decades?
}

\author{
A. Dupuy \\ Faculty of Economics and Business Administration, Research Centre for \\ Education and the Labour Market, Maastricht University, P. O. Box 616, \\ NL-6200 MD, The Netherlands \\ E-mail: a.dupuy@roa.unimaas.nl
}

While the skill-premium has been rising sharply in the US and the UK for 20 years, the Dutch skill-premium decreased for much of that period and only started to rise in the early 90 s. In this article, we investigate whether the Dutch skill-premium will rise in the next decades. To answer this question, we forecast the skill-premium using the Katz and Murphy (1992) and the Krusell et al. (2000) models. The Katz and Murphy model (KM) explains demand shifts by skill-biased technological change in unobservable variables captured by a time trend. In contrast, the Krusell et al. model (KORV) explains demand shifts by (observable) changes in the capital stock under a capital-skill complementarity technology. The results show that while the KM model predicts that the skill-premium will have increased by $30 \%$ in 2020 , based on realistic predictions of the stock of capital, the KORV model predicts that the skill-premium will remain between -5 and $+5 \%$ of its 1996 level.

\section{Introduction}

In recent decades, the skill-premium has been rising sharply in the US and the UK. In contrast, in most continental European countries the skill-premium has been decreasing or stagnating (Freeman and Katz, 1994; Nickell and Bell, 1996) until recent years. However, in the 90s, the skill-premium started rising in Germany and the Netherlands for instance, see Acemoglu (2003), Leuven and Oosterbeek (2000) and
Jacobs (2004). At the same time, all developed countries have experienced a steadily increasing relative supply of skilled workers. There is a fairly documented literature that explains the rise in the US skill-premium by continuous shifts in the relative demand for skilled workers of a magnitude off-setting the increase in the relative supply (Katz and Murphy, 1992).

In the literature related to the rising skill-premium, two main explanations ${ }^{1}$ are often put forward.

\footnotetext{
${ }^{1}$ A third explanation put forward in the literature is the increasing international trade. However, several arguments (e.g. same timing in the trade and nontrade sectors) against this explanation are raised (Johnson, 1997; Acemoglu, 2002). A fourth explanation put forward is the institutional change (DiNardo et al., 1996; Lee 1999). Acemoglu (2002) raises serious arguments against this explanation. Regarding the minimum wage: the decrease of the minimum wage cannot explain the rise in wage dispersion observed above the median of the wage distribution. Regarding the unions: wrong timing of deunionization and wage inequality, and inconsistancy between the unionization and rising wage inequality in Canada through the 70 s and 80 s.
} 
The skill-biased technological change (SBTC) explanation, led by Katz and Murphy (1992), Bound and Johnson (1992), Berman et al. (1994) and Autor et al. (1998) and Acemoglu (2002) is the most dominant in the literature. The argument reads as follows. New technologies are relatively more complementary with skilled workers than with unskilled workers. These new technologies when used in the production process therefore shift the relative demand for skilled workers upward. The SBTC effects on the skillpremium are captured in the Katz and Murphy (1992) model (KM model from now on) by regressing the log skill-premium on a time trend. The second explanation has it roots in the capital-skill complementarity in production. ${ }^{2}$ Skilled workers are more complementary to capital than unskilled workers, so that a decrease in the price of capital shifts the relative demand of skilled workers upward (Krusell et al., 2000; Beaudry and Green, 2003). The capitalskill complementarity effects on the skill-premium are captured in the Krusell et al. (2000) model (KORV model from now on) by regressing the log skillpremium on the log capital stock. ${ }^{3}$

Although the Netherlands experienced a decrease in the skill-premium through the $70 \mathrm{~s}$ and $80 \mathrm{~s}$, the skill-premium increased notably since the mid 90s (Leuven and Oosterbeek, 2000; Jacobs, 2004). The major reason for this is the slower growth of the skill supply observed since the beginning of 90s. This raises the question whether the Dutch skill-premium will continue to increase in the years to come like it did in the US for the last 20 years and whether the race between schooling and technology is lost by schooling (Tinbergen, 1975)?

To investigate this question we forecast the skillpremium to 2020 using the KM model, where skillbiased technological change is captured by a time trend and the KORV model, where SBTC are brought about by (observable) changes in the capital stock under a capital-skill complementarity technology. We first estimate parameters of the two models on the span 1969 to 1996 for the Netherlands. Using predictions for the relative skill supply, a first set of forecasts is derived from the Katz and Murphy
(1992) model. These forecasts are similar to those derived by Jacobs (2004). A second set of forecasts is generated from the Krusell et al. (2000) model. Four scenarios of the change in the stock of capital are considered. In the first scenario, the stock of capital will increase at an annual rate of $10 \%$ (equivalent to the highest growth rate in five successive years (19821986) observed during the last decades), in the second scenario, the stock of capital equipment will increase at an annual rate of $6 \%$ (equivalent to the growth rate observed between 1969 and 1996), in a third scenario, it grows at 3\% per year (its growth rate in the last 5 years observed, 1992-1996). In the fourth scenario, we use recent forecasts made by the CPB Netherlands Bureau for Economic Policy Analysis indicating that the stock of capital will rise at an annual rate of $1.6 \%$ through $2010 .{ }^{4}$

The article is organized as follows. In Section II we present the KM and KORV model. In Section III we discuss the data used for empirical analysis. In Section IV we present the empirical results. Section V concludes.

\section{The Model}

In this article we analyse the schedule of the skillpremium in the Netherlands. The analysis rests on a general aggregate production function that nests the two sources of changes in the skill-premium: the substitution effect that arises from shifts in the relative supply of skilled labour and the demand shift effect due to skill-biased technological change. We distinguish SBTC brought about by unobservable variables and captured by a time trend, the $\mathrm{KM}$ model, from SBTC brought about by (observable) changes in the price of capital when the production technology is characterized by capital-skill complementarity, the KORV model.

Let the aggregate production function be $Y_{t}=F\left(\theta_{s t} L_{s t}, \theta_{u t} L_{u t}, K_{t}\right)$, where $L_{s t}$ and $L_{u t}$ represent respectively the supply of skilled and unskilled labour, $\theta_{s t}$ and $\theta_{u t}$ represent respectively the

\footnotetext{
${ }^{2}$ See, e.g. Rosen (1968), Griliches (1969), Grant (1979) and Hamermesh (1993).

${ }^{3}$ The explanation of increasing skill premium by the capital-skill complementarity has often been rejected because of its apparent inconsistency with a constant share of capital in the economy. However, though an aggregate production function with a unitary elasticity of substitution between capital and labour (aggregate of skilled and unskilled labour) ensures the constancy of the share of capital, there are more flexible forms of aggregate production function satisfying the postulate of the constant share of capital. Indeed, a production function with a greater-than-unity elasticity of substitution accompanied by a labour augmenting technological change would be consistent with constant shares of labour and capital, see e.g. Brown and De Cani (1963), Kennedy (1964), David and van de Klundert (1965), Sato (1970) and Yuhn (1991).

${ }^{4}$ See CPB (2004).
} 
possibility of skilled and unskilled labour augmenting factors, i.e. skill-biased technological change brought about by unobservable variables, and $K_{t}$ is the stock of capital at time $t$.

The equation on which we base our empirical investigation is derived from the marginal product conditions for wages, the assumption of competitive input markets, $\partial F / \partial L_{j}=w_{j}$ and $\partial F / \partial K=r$, that is

$$
\begin{aligned}
& w_{s t}=\frac{\theta_{s t} \partial F}{\partial L_{s t}} \\
& w_{u t}=\frac{\theta_{u t} \partial F}{\partial L_{u t}}
\end{aligned}
$$

where $w_{j}$ is the wage rate of labour $j, j=\{u, s\}$.

The log-linear approximation of Equations 1 and 2 can be written as:

$\ln w_{s t}=\alpha_{0}+\alpha_{s} \ln \left(\theta_{s t} L_{s t}\right)+\alpha_{u} \ln \left(\theta_{u t} L_{u t}\right)+\alpha_{K} \ln K_{t}+\ln \theta_{s t}$

$\ln w_{u t}=\beta_{0}+\beta_{s} \ln \left(\theta_{s t} L_{s t}\right)+\beta_{u} \ln \left(\theta_{u t} L_{u t}\right)+\beta_{K} \ln K_{t}+\ln \theta_{u t}$

Using Equations 3 and 4, the log skill-premium $\pi_{t} \equiv \ln w_{s t}-\ln w_{u t}$ can then be written as:

$$
\begin{aligned}
\pi_{t}= & \alpha_{0}-\beta_{0}+\left(1+\alpha_{s}-\beta_{s}\right) \ln \theta_{s t}+\left(\alpha_{u}-\beta_{u}-1\right) \ln \theta_{u t} \\
& +\left(\alpha_{s}-\beta_{s}\right) \ln L_{s t}+\left(\alpha_{u}-\beta_{u}\right) \ln L_{u t}+\left(\alpha_{K}-\beta_{K}\right) \ln K_{t}
\end{aligned}
$$

Note that for $\alpha_{s}-\beta_{s}=\beta_{u}-\alpha_{u}$ we have:

$$
\begin{aligned}
\pi_{t}= & \alpha_{0}-\beta_{0}+\left(1+\alpha_{s}-\beta_{s}\right) \ln \frac{\theta_{s t}}{\theta_{u t}} \\
& +\left(\alpha_{s}-\beta_{s}\right) \ln \frac{L_{s t}}{L_{u t}}+\left(\alpha_{K}-\beta_{K}\right) \ln K_{t}
\end{aligned}
$$

The term in second row of Equation 5 captures the effect of skilled-biased technological change brought about by unobservable variables. The term in the third row captures the substitution effect induced by shifts in the relative skill supply and the term in the last row captures observable SBTC via the capitalskill complementarity.

The capital-skill complementarity effect on the skill-premium can further be decomposed into an impulse due to changes in the stock of capital, i.e. $d \ln K_{t}$ and a multiplicative effect depending on the technological parameters of substitution between capital and skilled and unskilled labour. Since capital and unskilled workers are usually strong substitutes, we expect $\beta_{K}<0$. In contrast, we expect capital and skilled labour to be complementary and therefore $\alpha_{K}>0$.

Imposing $\left(\alpha_{K}-\beta_{K}\right)=0$ in Equation 6 we obtain the KM model.

\section{KM model}

$$
\pi_{t}=\gamma_{0}+\gamma_{1} \ln \frac{L_{s t}}{L_{u t}}+\gamma_{2} t+\varepsilon_{t}
$$

where $\left(1+\alpha_{s}-\beta_{s}\right) \ln \left(\theta_{s t}\right) /\left(\theta_{u t}\right)=\gamma_{2} t, \quad\left(\alpha_{s}-\beta_{s}\right)=\gamma_{1}$ and $\alpha_{0}=\beta_{0}=\gamma_{0}$, and the elasticity of substitution between skilled and unskilled labour is $\sigma=1 / \gamma_{1}$.

Imposing $\ln \left(\theta_{s t}\right) /\left(\theta_{u t}\right)=\delta$ to be constant through time in Equation 6, we obtain the KORV model.

\section{KORV model}

$$
\pi_{t}=\gamma_{0}^{\prime}+\gamma_{1}^{\prime} \ln \frac{L_{s t}}{L_{u t}}+\gamma_{3} \ln K_{t}+\varepsilon_{t}^{\prime}
$$

where $\quad\left(\alpha_{K}-\beta_{K}\right)=\gamma_{3}, \quad\left(\alpha_{s}-\beta_{s}\right)=\gamma_{1}^{\prime} \quad$ and $\alpha_{0}-\beta_{0}=\gamma_{0}^{\prime}$.

\section{The Data}

The data we use consists of annual time-series of capital and labour for the Dutch economy between 1969 and $1996 .{ }^{5}$ We use the National accounts timeseries collected by Statistics Netherlands, CBS (1999). The data consists of capital and labour accounts. The capital accounts data contains five investment series. Investment in machines, transports, computers, materials and the aggregate of these four investments that form investments in equipment are available in current prices. We make use of the respective priceindex for the period 1969 to 1996 to deflate the five series of investment and obtain measures of investments in 1969 prices. The stock of capital for the five series is then calculated using the perpetual inventory method. The capital stock in 1969 is set to the investment level in 1969. We recursively construct the stock of capital the next period using investment and a depreciation ratio of 0.05 for equipment, machines and transports and 0.10 for materials and 0.15 for computers. ${ }^{6}$ In the remaining part of this study we use the series on the stock of capital equipment. The series of capital equipment are normalized to 1 in 1969. As illustrated in Fig. 1 the stock of capital

\footnotetext{
${ }^{5}$ The data can be obtained from the author's website, http://www.fdewb.unimaas.nl/roa. More recent data was not available at the time the analyses were done.

${ }^{6}$ Other plausible rates of depreciation did not alter the results significantly.
} 


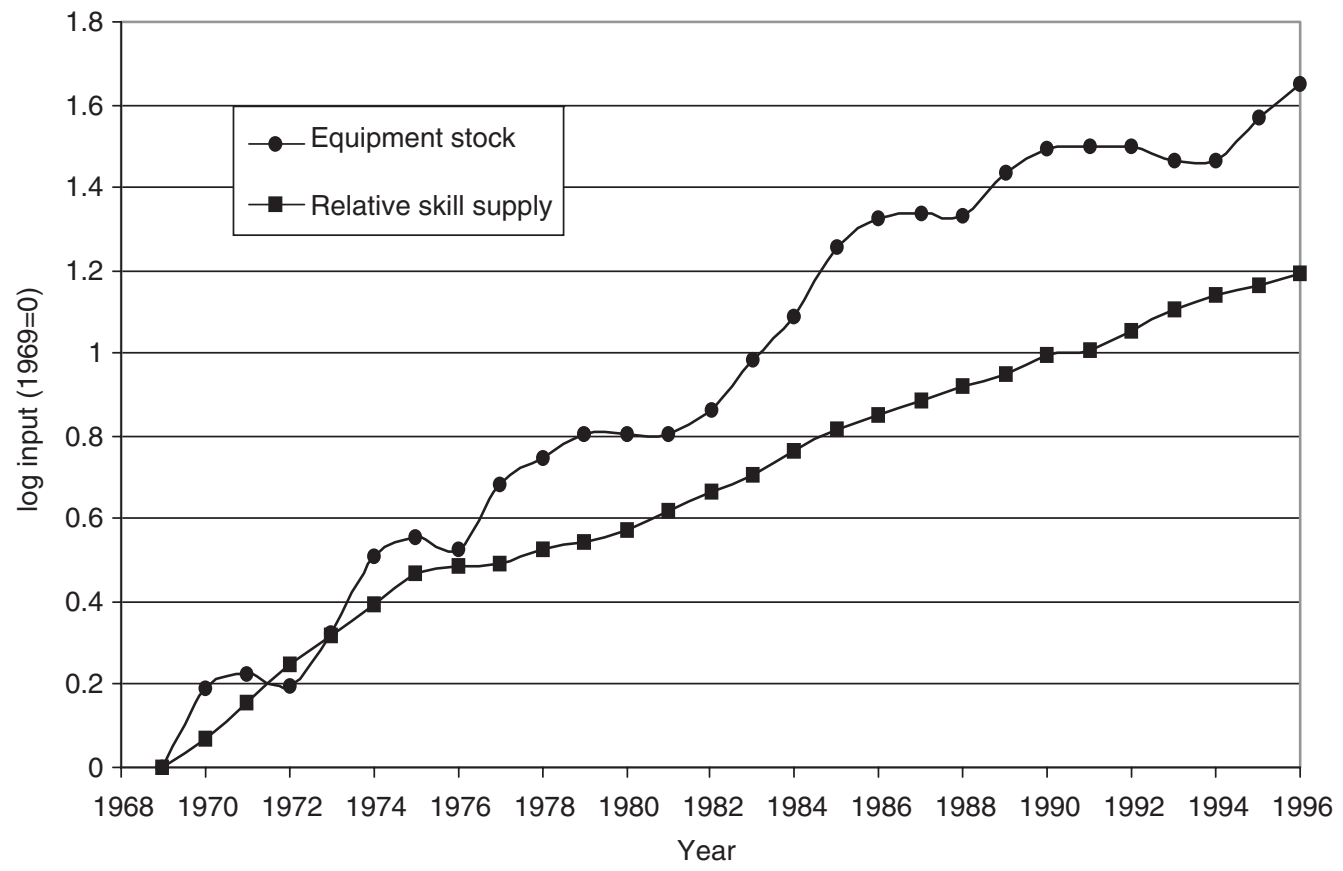

Fig. 1. Time-series of equipment stock and relative supply of skilled labour in the Netherlands (1969-1996)

equipment increases almost steadily throughout the period at a yearly rate of $6 \%$.

Since we are interested in developments in the skillpremium, we distinguish between skilled and unskilled labour. We use the time-series collected by Statistics Netherlands (CBS). ${ }^{7}$ We define low-skilled workers by workers with primary or secondary education and skilled workers by higher educated workers. The relative supply of skilled workers is the ratio of the number of skilled workers, expressed in man-years, to the number of unskilled workers, also expressed in man-years. Wages are based on gross hourly wages and we define the skill-premium as the ratio of the wages of skilled workers and unskilled workers. The supply of both skilled and unskilled workers is normalized to 1 in 1969.

The data indicates that the supply of skilled workers has been multiplied by a factor 3.5 in the period of observation while the supply of unskilled workers remained fairly stable, as shown in Fig. 1.

As indicated in Fig. 2, the skill-premium decreases, first moderately through 1979 at an annual rate of $0.6 \%$, then sharply between 1979 and 1985 at an annual rate of $2.8 \%$, and remains fairly stable to 1992. From 1992 to 1996, the skill-premium slightly increases at an annual rate of $0.4 \%$.

\section{Empirical Results}

\section{Estimation of the KM and KORV models}

Our empirical objective is to get estimates of the parameters of the KM and KORV models to make forecasts of the skill-premium in the Netherlands. This could be done by ordinary least squarers (OLS) estimations of Equations 7 and 8. However, when estimating both parameters $\gamma_{1}$ and $\gamma_{2}$ in Equation 7 or $\gamma_{1}^{\prime}$ and $\gamma_{3}$ in Equation 8 simultaneously, the parameters have the wrong sign due to strong multicollinearity in the series. We therefore regress the skill-premium series on the relative supply of skilled labour at given plausible time trend parameters (KM model) or capital-skill complementarity parameters (KORV model) as suggested by Katz and Murphy (1992) and Jacobs (2004).

The estimation results reported in Table 1 indicate that at comparable elasticities of

\footnotetext{
${ }^{7}$ The labour series and wage series we use are simply obtained by aggregating $l_{u}=l_{p r}+l_{s e}$ for unskilled labour (where $l_{p r}$ and $l_{s e}$ are respectively the number of man-year with primary and secondary education and weighting $w_{u}=\left(l_{p r} w_{p r}+l_{s e} w_{s e}\right) / l_{u}$ for the unskilled wage.
} 


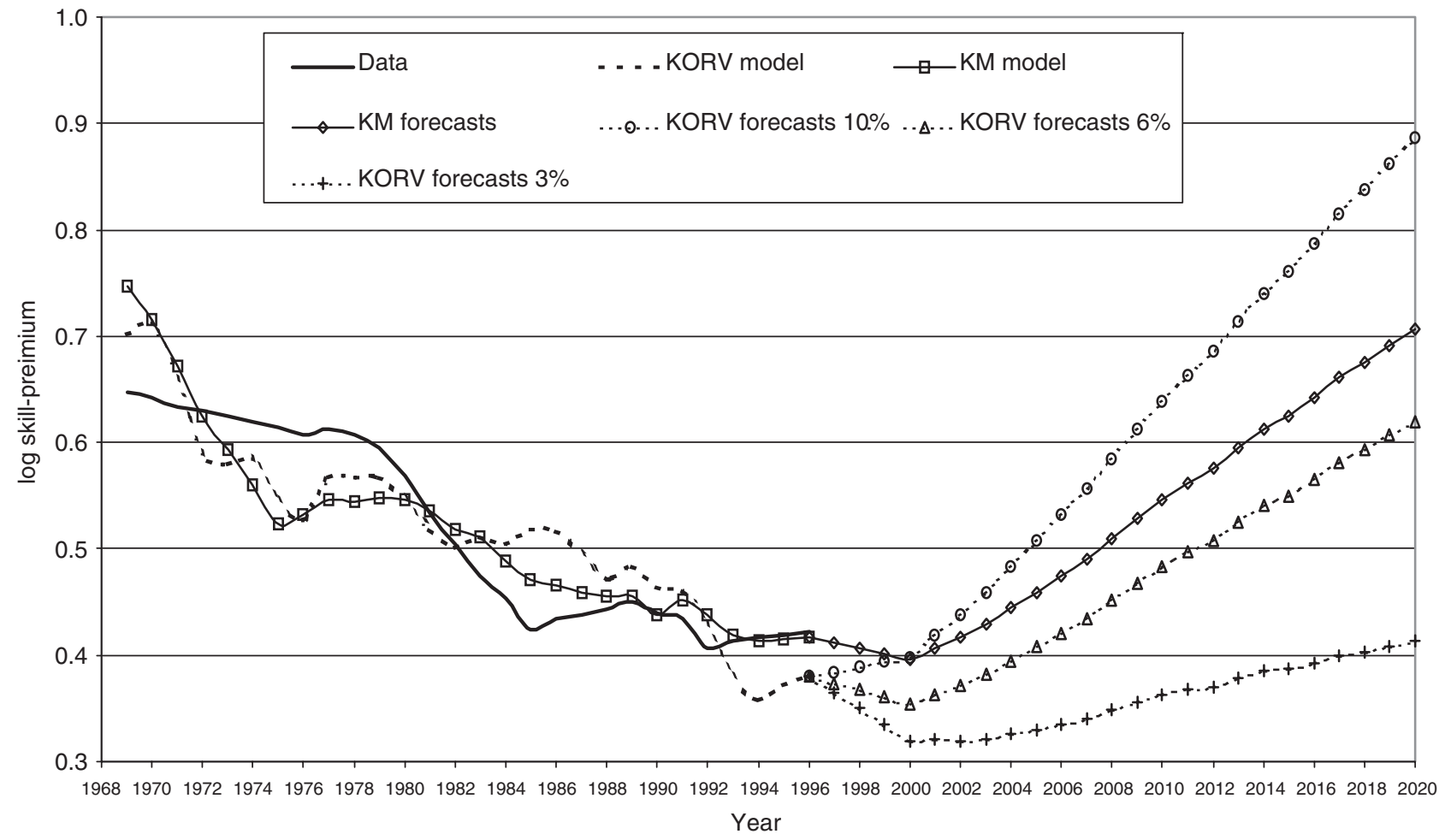

Fig. 2. Ex post (1969-1996) and ex ante (1997-2020) predictions of the skill-premium schedule in the Netherlands using the KM and KORV models

Table 1. Parameter estimates of the skill-premium in levels

\begin{tabular}{|c|c|c|c|c|c|}
\hline \multirow[b]{2}{*}{ KM Model } & \multicolumn{5}{|l|}{ Levels } \\
\hline & \multicolumn{2}{|c|}{$\log \left(L_{s t} / L_{u t}\right): \gamma_{1}$} & \multirow{2}{*}{$\begin{array}{l}\sigma=-\left(1 / \gamma_{1}\right) \\
2.03\end{array}$} & \multirow{2}{*}{$\begin{array}{l}R_{\text {adj }}^{2} \\
0.95\end{array}$} & \multirow{2}{*}{$\frac{\text { DW }}{0.97}$} \\
\hline Time: $\gamma_{2}=0.01$ & $-0.492^{\mathrm{a}}$ & $(0.021)$ & & & \\
\hline Time: $\gamma_{2}=0.02$ & $-0.731^{\mathrm{a}}$ & $(0.025)$ & 1.37 & 0.97 & 1.19 \\
\hline Time: $\gamma_{2}=0.03$ & $-0.970^{\mathrm{a}}$ & $(0.031)$ & 1.03 & 0.97 & 1.32 \\
\hline Time: $\gamma_{2}=0.04$ & $-1.120^{\mathrm{a}}$ & & 0.89 & 0.98 & 1.38 \\
\hline KORV model & \multicolumn{2}{|c|}{$\log \left(L_{s t} / L_{u t}\right): \gamma_{1}^{\prime}$} & $\sigma=-\left(1 / \gamma_{1}^{\prime}\right)$ & $R_{\text {adj }}^{2}$ & DW \\
\hline $\log K_{t}: \gamma_{3}=0.10$ & $-0.397^{\mathrm{a}}$ & $(0.021)$ & 2.52 & 0.93 & 0.20 \\
\hline $\log K_{t}: \gamma_{3}=0.20$ & $-0.542^{\mathrm{a}}$ & $(0.024)$ & 1.85 & 0.95 & 0.24 \\
\hline $\log K_{t}: \gamma_{3}=0.30$ & $-0.686^{\mathrm{a}}$ & $(0.028)$ & 1.46 & 0.96 & 0.29 \\
\hline $\log K_{t}: \gamma_{3}=0.40$ & $-0.831^{\mathrm{a}}$ & $(0.032)$ & 1.20 & 0.96 & 0.34 \\
\hline
\end{tabular}

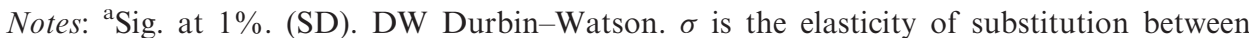
skilled and unskilled labour. Figures in italics indicate the prefered estimates.

substitution, both the model with time trend and the model with capital equipment explain roughly the same percentage of the variance in the skillpremium schedule. The fit of both models is globally equivalent as indicated by the adjusted $R^{2}$ statistics and illustrated in Fig. 2. Both models seem to be equally suited to forecast ex post the skill-premium in the Netherlands. It is empirically impossible to decide which model should be preferred, choosing in favour of the KM or the
KORV model, therefore, depends merely on one's economic belief on whether capital and skilled labour are complementary in production or not.

To compare the magnitude of the capital-skill complementarity effect to that of the time trend, we decompose the change in the skill-premium into two effects. The substitution effect is induced by the increased relative supply of skilled workers. The demand effect is either due to SBTC in unobservable variables in the KM model or to SBTC via the 
Table 2. Comparison of changes in the skill-premium under SBTC and capital-skill complementarity

\begin{tabular}{|c|c|c|c|c|c|c|c|}
\hline \multirow[b]{2}{*}{ Period } & \multicolumn{3}{|c|}{ KM, Contribution of } & \multicolumn{3}{|c|}{ KORV, Contribution of } & \multirow{2}{*}{$\frac{\text { Data }}{\pi_{t}}$} \\
\hline & Time & $\log \left(L_{s t} / L_{u t}\right)$ & $\hat{\pi}_{t}$ & $\log K_{t}$ & $\log \left(L_{s t} / L_{u t}\right)$ & $\hat{\pi}_{t}$ & \\
\hline $69-81$ & 2 & -3.75 & -1.75 & 1.99 & -3.52 & -1.54 & -1.09 \\
\hline $81-96$ & 2 & -2.73 & -0.73 & 1.69 & -2.56 & -0.87 & -0.59 \\
\hline $69-96$ & 2 & -3.22 & -1.22 & 1.83 & -3.03 & -1.19 & -0.83 \\
\hline
\end{tabular}

Note: The contributions are expressed in annual percentage rates.

capital-skill complementarity in production in the KORV model. We split the period into two sub-periods. The period 1969 to 1981 is characterized by an annual growth in capital equipment of $6.7 \%$ and the period 1981 to 1996 is characterized by a slower growth of capital equipment, annual rate of $5.7 \%$. The demand and substitution contributions, expressed in annual percentage rates, are reported in Table 2. In the KM model, demand shifts contribute to increase the skill-premium by $2 \%$ per year. In the KORV model, demand shifts contribute to increase the skill-premium by $1.83 \%$ per year. Since in the KM model, the time trend captures the effect of all variables that are highly linearly correlated with time and omitted in the KM model, it also includes the effects of capital equipment. Therefore, we can conclude that between 1969 and 1996, 92\% of the demand shifts, $1.83 / 2=0.915$ in Table 2 , are induced by the growth of equipment stock, although the importance of unobserved sources tend to be larger in the last period, 15\% between 1981 and 1996 $(1.69 / 2=0.845)$, than in the beginning period, $0.5 \%$ between 1969 and $1981(1.99 / 2=0.995)$.

\section{Robustness checks}

Is capital irrelevant? The capital-skill complementarity explanation is often rejected in the literature (Acemoglu, 2002) because of its apparent lower explanatory power. Acemoglu (2002) for instance, regresses the US log skill-premium with on the one hand a time trend and on the other hand the log price of capital equipment. The $R_{\text {adj }}^{2}$ associated to the time trend model is 0.90 and larger than that of the regression with the price of capital, i.e. 0.86. Based on the $R^{2}$ adjusted statistics, the KM model should be preferred to the KORV model. However, we argue that this way of testing hypotheses is biased against the capital-skill complementarity hypothesis, since the time variable picks up the effects of all unobserved variables linearly correlated with time (capital included). To show this, we generated a skill-premium series (28 observations) by $\quad \tilde{\pi}_{t}=1+2 \ln \left(L_{s t} / L_{u t}\right)+3 \ln K_{t}+\varepsilon_{t}, \quad$ where $\varepsilon_{t} \rightarrow \operatorname{NID}(0,1)$ and regressed this skill-premium series once with capital (the true model) and once with time trend instead. We then calculated the Error Sum of Squares of both regressions and compared the results. We found that for 2995 out of 10000 replications, the ESS of the capital model exceeds that of the time trend model. This means that with a probability of $30 \%$, we reject the capital-skill complementarity hypothesis in favour of the alternative hypothesis of unobserved SBTC when the true hypothesis is capital-skill complementarity. We also ran 10000 replications of the reverse test (true hypothesis is time trend: the skill-premium is generated with time trend) and in none of these replications were the ESS associated with the capital regression lower than the ESS associated with the time trend.

Robustness of the parameters. The Durbin-Watson statistics, reported in Table 1, indicate a possible spurious relationship in the equations of the model. The augmented Dickey-Fuller statistics indicate that the $\log$ skill-premium series and $\log$ equipment stock are not stationary, integrated of order 1 $\left(\operatorname{ADF}\left(\pi_{t}\right)=-0.57\right.$ and $\left.\operatorname{ADF}\left(\ln K_{t}\right)=-1.65\right)$ whereas the possibility that the $\log$ skill supply series are stationary can not be rejected at $5 \%$ $\left(\operatorname{ADF}\left(\ln \left(L_{s t}\right) /\left(L_{u t}\right)\right)=-3.41\right)$. We therefore regressed Equations 7 and 8 in first differences to investigate the sensitivity of the long-run model estimates. The estimates of the skill-premium equation are reported in Table 3. The estimated parameters are of relatively similar magnitude in levels and first differences and the parameters remain significant when estimated with first differences. The results are reassuring regarding the findings presented in this article.

Different capital series. We check the robustness of our results with respect to the choice of the capital variable by replacing the equipment capital by two other measures of capital, namely the stock of computers and the stock of machines. These two measures of capital grow at very different rates during the period 1969 to 1996 , as can be seen from 
Table 3. Parameter estimates of the skill-premium in first differences

\begin{tabular}{|c|c|c|c|}
\hline \multicolumn{4}{|l|}{ First-differences } \\
\hline KM Model & $\log \left(L_{s t} / L_{u t}\right): \gamma_{1}$ & $\sigma=-\left(1 / \gamma_{1}\right)$ & $R_{\text {adj }}^{2}$ \\
\hline Time: $\gamma_{2}=0.01$ & $-0.349^{\mathrm{a}}(0.021)$ & 2.87 & 0.57 \\
\hline Time: $\gamma_{2}=0.02$ & $-0.530^{\mathrm{a}} \quad(0.068)$ & 1.89 & 0.69 \\
\hline Time: $\gamma_{2}=0.03$ & $-0.711^{\mathrm{a}} \quad(0.081)$ & 1.41 & 0.74 \\
\hline Time: $\gamma_{2}=0.04$ & $-0.892^{\mathrm{a}} \quad 1.12$ & 0.76 & 0.76 \\
\hline KORV Model & $\log \left(L_{s t} / L_{u t}\right): \gamma_{1}^{\prime}$ & $\sigma=-\left(1 / \gamma_{1}^{\prime}\right)$ & $R_{\text {adj }}^{2}$ \\
\hline $\log K_{t}: \gamma_{3}=0.10$ & $-0.284^{\mathrm{a}}(0.060)$ & 3.52 & 0.44 \\
\hline $\log K_{t}: \gamma_{3}=0.20$ & $-0.402^{\mathrm{a}} \quad(0.078)$ & 2.49 & 0.49 \\
\hline $\log K_{t}: \gamma_{3}=0.30$ & $-0.520^{\mathrm{a}} \quad(0.100)$ & 1.92 & 0.49 \\
\hline $\log K_{t}: \gamma_{3}=0.40$ & $-0.637^{\mathrm{a}}(0.124)$ & 1.57 & 0.48 \\
\hline
\end{tabular}

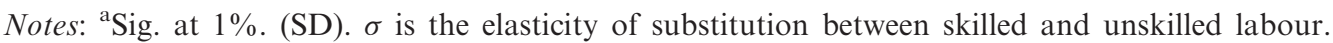
Figures in italics indicate the prefered estimates.

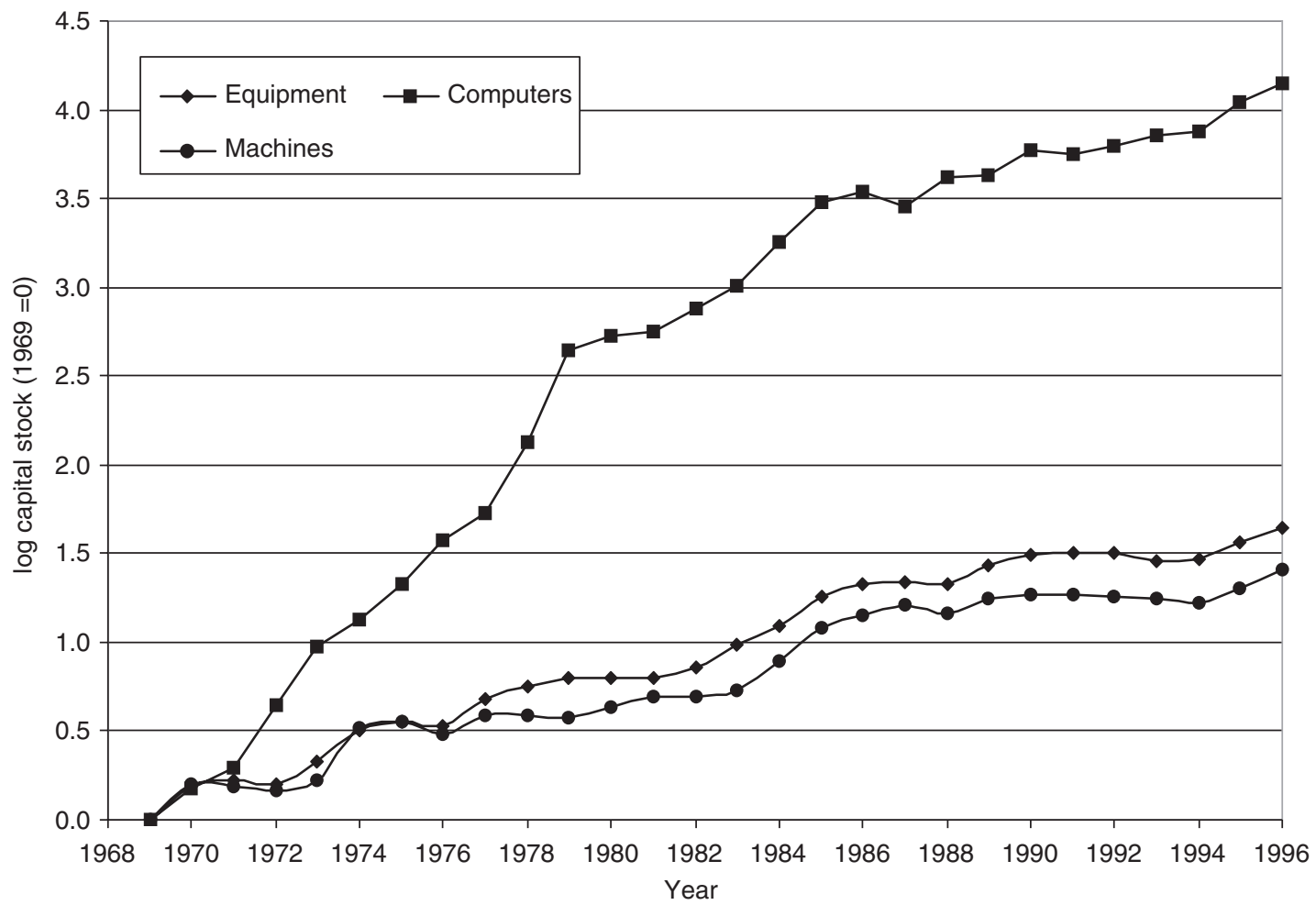

Fig. 3. Time-series of equipment stock, computers stock and machines stock in the Netherlands (1969-1996)

Fig. 3. The computers stock series increases sharply in the period 1969 to 1979, annual rate of nearly $26 \%$ per year and slows down through 1996 to a yearly rate of $8.9 \%$. In contrast, the machines stock increases relatively constantly in the period 1969 to 1996 at a moderate annual rate of $5.2 \%$.

We replicate the analysis ran for capital equipment but for computers and machines stock instead. The results of the levels and first-differences estimations of Equation 8 with computers and machines instead of capital equipment are reported in Table 4. The percentage explained of the variance in the skill-premium is insensitive to the type of capital considered as indicated by the various $R_{\text {adj }}^{2}$ statistics (i.e. 0.96 for equipment, 0.95 for machines and 0.94 for computers).

\section{Forecasts of the Dutch skill-premium in 2020}

We make use of the supply forecasts for skilled and unskilled workers provided by CBS and CPB. 
Table 4. Parameter estimates of the skill-premium in levels and first differences for computers and machines

\begin{tabular}{|c|c|c|c|c|c|c|}
\hline & \multicolumn{3}{|l|}{ Level } & \multicolumn{3}{|l|}{ First-differences } \\
\hline & $\log \left(L_{s t} / L_{u t}\right): \gamma_{1}^{\prime}$ & $\sigma=-\left(1 / \gamma_{1}^{\prime}\right)$ & $R_{\text {adj }}^{2}$ & $\log \left(L_{s t} / L_{u t}\right): \gamma_{1}^{\prime}$ & $\sigma=-\left(1 / \gamma_{1}^{\prime}\right)$ & $R_{\text {adj }}^{2}$ \\
\hline $\begin{array}{l}\text { Computers } \\
\log K_{t}: \gamma_{3}=0.30 \\
\log K_{t}: \gamma_{3}=0.20 \\
\log K_{t}: \gamma_{3}=0.12 \\
\log K_{t}: \gamma_{3}=0.10\end{array}$ & $\begin{array}{l}-1.381^{\mathrm{a}}(0.064) \\
-1.005^{\mathrm{a}}(0.046) \\
-0.704^{a}(0.033) \\
-0.629^{\mathrm{a}}(0.030)\end{array}$ & $\begin{array}{l}0.72 \\
0.99 \\
1.42 \\
1.59\end{array}$ & $\begin{array}{l}0.95 \\
0.95 \\
0.94 \\
0.94\end{array}$ & $\begin{array}{l}-1.072^{\mathrm{a}}(0.177) \\
-0.770^{\mathrm{a}}(0.126) \\
-0.529^{\mathrm{a}}(0.088) \\
-0.469^{\mathrm{a}}(0.080)\end{array}$ & $\begin{array}{l}0.93 \\
1.30 \\
1.89 \\
2.13\end{array}$ & $\begin{array}{l}0.57 \\
0.57 \\
0.55 \\
0.55\end{array}$ \\
\hline $\begin{array}{l}\text { Machines } \\
\log K_{t}: \gamma_{3}=0.30 \\
\log K_{t}: \gamma_{3}=0.40 \\
\log K_{t}: \gamma_{3}=0.50\end{array}$ & $\begin{array}{l}-0.620^{\mathrm{a}}(0.028) \\
-0.742^{\mathrm{a}}(0.032) \\
-0.864^{\mathrm{a}}(0.031)\end{array}$ & $\begin{array}{l}1.61 \\
1.35 \\
1.16\end{array}$ & $\begin{array}{l}0.95 \\
0.95 \\
0.95\end{array}$ & $\begin{array}{l}-0.500^{\mathrm{a}}(0.113) \\
-0.611^{\mathrm{a}}(0.142) \\
-0.722^{\mathrm{a}}(0.182)\end{array}$ & $\begin{array}{l}2.00 \\
1.64 \\
1.39\end{array}$ & $\begin{array}{l}0.41 \\
0.39 \\
0.38\end{array}$ \\
\hline
\end{tabular}

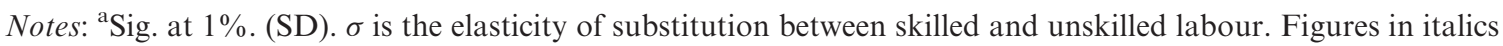
indicate the prefered estimates.

Table 5. Decomposition of the skill premium forecasts to 2020 for the KM and KORV models and realistic scenarios of the growth of capital stock

\begin{tabular}{llllll}
\hline Model: scenario & Time & $\log \mathrm{K}_{\mathrm{t}}$ & $\log \left(L_{s t} / L_{u t}\right)$ & $\hat{\pi}_{t}$ & $\left(\widehat{\pi_{2020}}-\widehat{\pi_{1996}}\right) \%$ \\
\hline KORV $: \dot{K}=10 \%$ & - & 2.86 & -0.68 & 2.18 & +50 \\
KORV $: \dot{K}=6$ & - & 1.75 & -0.68 & 1.07 & +25 \\
KORV $: \dot{K}=3$ & - & 0.86 & -0.68 & 0.18 & +5 \\
KORV $: \dot{K}=1.6$ & - & 0.50 & -0.68 & -0.18 & -5 \\
KORV $: \dot{K}=6.75(=\mathrm{KM})$ & - & 1.96 & -0.68 & 1.28 & +30 \\
KM & 2 & - & -0.72 & 1.28 & +30 \\
\hline
\end{tabular}

Note: The contributions are expressed in annual percentage rates.

The data provides an estimation of the number of persons employable in the labour force from 2000 to 2020. The forecasts for the period 1997 to 2000 are obtained by linear extrapolation of the series.

We make predictions of the relative wage of skilled workers using deterministic scenarios of the stock of capital. The four deterministic scenarios considered are:

(i) The stock of capital grows at an annual rate of $10 \%$ during the period 1997 to 2020 , corresponding to the highest historical growth rate in five consecutive years (1982-1986) between 1969 and 1996.

(ii) The stock of capital grows at $6 \%$ per year, corresponding to the average rate during the period 1969 to 1996.

(iii) The stock of capital grows at 3\% per year, corresponding to the growth rate observed in the last 5 years, 1992-1996.

(iv) As predicted by the CPB Netherlands Bureau for Economic Policy Analysis, the stock of capital rises at an annual rate of $1.6 \%$ through $2020 .^{8}$

The decomposition of the skill-premium forecasts under the different models and scenarios is reported in Table 5.

Using the KM model, we predict that the skillpremium will rise at an annual rate of $1.3 \%$ so that by 2020, the skill-premium will be $30 \%$ above its 1996 level (Jacobs, 2004). To meet this result with the KORV model, that is accounting for the capital-skill complementarity in production, the stock of capital would have to rise continuously until 2020 at an annual rate of $6.8 \%$. This implied annual growth rate in the stock of capital is twice the annual rate observed in the last 5 years of our sample 1992-1996 and lies $0.8 \%$ points above the average rate in the span 1969-1996.

The increase in the skill-premium, as predicted by the KORV model, varies from $50 \%$ when capital stock rises $10 \%$ per year to $-5 \%$ when the stock of capital grows at $1.6 \%$ per year through 2020 .

${ }^{8}$ The CPB (2004) forecasts a moderate growth in the stock of capital of $1.6 \%$ per year through 2010 . In this article, we extrapolate this forecasts to 2020. Note that this scenario is realistic at sight of the recent decrease in firms' investments, observed in the Netherlands, $-12 \%$ between 2000 and 2004. 


\section{Conclusion}

The answer to the question: is the race between schooling and technology, e.g. Tinbergen (1975) lost by schooling? is empirically blurred. Economists that support the idea that shifts in the demand for skilled labour result from skill-biased technological change in unobservable variables would answer positively $(30 \%$ increase in the skill-premium by 2020$)$. In contrast, the answer of economists in favour of the capital-skill complementarity in production will depend on their expectations regarding the evolution of the price of capital. If the price of capital keeps falling at a pace comparable to that of the last decades, by 2020 the race would be lost by schooling. However, if the price of capital decreases at the same pace it did in the 90s, the skill-premium will stabilize.

\section{Acknowledgments}

I would like to thank Lex Borghans, Frank Cörvers, Bart Golsteyn, Ben Kriechel, Philip Marey, Christophe Meng, Catherine Morrison Paul, Inge Sieben, Wendy Smits and Bas ter Weel for helpful comments on earlier drafts.

\section{References}

Acemoglu, D. (2002) Technical change, inequality and the labor market, Journal of Economic Literature, 40, $7-72$.

Acemoglu, D. (2003) Cross-country inequality trends, Economic Journal, 113, 121-49.

Autor, D., Katz, L. and Krueger, A. (1998) Computing inequality: have computers changed the labor market?, Quarterly Journal of Economics, 113, 1169-213.

Beaudry, P. and Green, D. (2003) Wages and employment in the United States and Germany: what explains the differences?, American Economic Review, 93, 573-602.

Berman, E., Bound, J. and Griliches, Z. (1994) Changes in the demand for skilled labor within US manufacturing: evidence from annual survey of manufactures, Quarterly Journal of Economics, 109, 367-97.

Bound, J. and Johnson, G. (1992) Changes in the structure of wages during the 1980's: an evaluation of alternative explanations, American Economic Review, 82, 371-92.

Brown, M. and De Cani, J. (1963) Technological change and the distribution of income, International Economic Review, 4, 289-309.
CPB (2004) Macro Economische Verkenning, CPB Reports.

David, P. and Van De Klundert, T. (1965) Biased efficiency growth and capital-labor substitution in the US, 1899-1960, American Economic Review, 55, 357-93.

DiNardo, J., Fortin, N. and Lemieux, T. (1996) Labor market institutions and the distribution of wages, 1979-1992: a semi-parametric approach, Econometrica, 64, 1001-44.

Freeman, R. and Katz, L. (1994) Rising wage inequality: the United States vs. other advanced countries, pp. 29-62 in Working under Different Rules, Freeman, R. (ed). Russell Sage Foundation: New York.

Grant, J. (1979) Labor Substitution in U.S. Manufacturing, Ph.D. thesis, Michigan State University.

Griliches, Z. (1969) Capital-skill complementarity, Review of Economics and Statistics, 51, 465-8.

Hamermesh, D. (1993) Labor Demand, Princeton University Press, Princeton, NJ.

Jacobs, B. (2004) The lost race between schooling and technology, De Economist, 152, 47-78.

Johnson, G. (1997) Changes in earnings inequality: the role of demand shifts, Journal of Economic Perspectives, 11, $41-54$.

Katz, L. and Murphy, K. (1992) Changes in relative wages, 1963-1987: supply and demand factors, Quarterly Journal of Economics, 107, 35-78.

Kennedy, C. (1964) Induced bias in innovation and the theory of distribution, Economic Journal, 74, $541-7$.

Krusell, P., Ohanian, L., Ríos-Rull, J.-V. and Violante, G. (2000) Capital-skill complementarity and inequality: a macroeconomic analysis, Econometrica, 68, 1029-53.

Lee, D. (1999) Wage inequality in the US during the 1980s: rising dispersion or falling minimum wage?, Quarterly Journal of Economics, 114, 941-1024.

Leuven, E. and Oosterbeek, H. (2000) Rendement van onderwijs stijgt, Economisch Statistische Berichten, 4262, 523-4.

Nickell, S. and Bell, B. (1996) Changes in the distribution of wages and unemployment in OECD countries, American Economic Review, Papers and Proceedings, 86, 302-8.

Rosen, S. (1968) Short-run employment variation on class-I railroads in the United States, 1947-1963, Econometrica, 36, 511-29.

Sato, R. (1970) The estimation of biased technical progress and the production function, International Economic Review, 11, 179-208.

Tinbergen, J. (1975) Income Distribution: Analysis and Policies, North-Holland, Amsterdam.

Yuhn, K. (1991) Economic growth, technological change biases, and the elasticity of substitution: a test of the de la Granville hypothesis, Review of Economics and Statistics, 73, 340-6. 